\title{
ENSAIO SOBRE UM MUNDO RURAL NA SERRA DA MANTIQUEIRA: UMA CAMPESINIDADE VIVA NO BAIRRO PEROBA
}

\author{
Ednilson Moisés de Lima e Silva ${ }^{1}$ \\ Viviane Guimarães Pereira ${ }^{2}$ \\ Tayrine Parreira Brito ${ }^{3}$ \\ Samanta Borges Pereira ${ }^{4}$
}

Este ensaio fotográfico tem como cenário um bairro rural pertencente ao município de Itajubá, na Serra da Mantiqueira, no sul de Minas Gerais: o bairro Peroba. Trata-se de um tipo de localidade bastante comum no Estado de Minas Gerais, cujas caracterizações estão em torno dos fortes laços de parentesco e vizinhança, relações intensas de seus moradores com o lugar e a natureza e dependência da agricultura para a manutenção da vida. Estes também são contornos que definem a maioria dos bairros rurais das mesorregiões localizadas nas e próximas às divisas dos estados de Minas Gerais, Mato Grosso do Sul, Goiás, Paraná, Rio de Janeiro e São Paulo, em que suas semelhanças, segundo o IBGE (1992; 2016), são mais ou menos correlativas.

Estas semelhanças rurais que o Instituto Brasileiro de Geografia e Estatísticas apresentou já o era feito na obra de Antônio Cândido (1968), em que o autor, ao reconstruir a história de vida do homem rural paulista, denominou esta região de Grande Paulistânia. Tratava-se de “certas porções do grande território escancarado pelas bandeiras e entradas das características iniciais do vicentino que se desdobraram numa variedade subcultural do tronco português”, que, segundo Cândido (1968: 35), permitiu a formação e consolidação da "cultura caipira". A caracterização de um bairro rural, nesta Grande Paulistânia, é definida como

[...] todo conjunto de casas e propriedades, suficientemente próximas para que se estabeleçam contatos sociais entre seus moradores. É um fragmento de comunidade rural em que existem certos tipos de parentesco ou de vizinhança, reforçados

\footnotetext{
${ }^{1}$ Universidade Federal de Itajubá, Brasil. E-mail: ednilsondelima@unifei.edu.br Orcid ID: http://orcid.org/0000-0002-7990-0030

${ }^{2}$ Universidade Federal de Itajubá, Brasil. E-mail: vgpereira@yahoo.com.br Orcid ID: http://orcid.org/0000-0003-4973-5764

${ }^{3}$ Universidade Estadual de Campinas, Brasil. E-mail: tayrinepb@gmail.com Orcid ID: http://orcid.org/0000-0001-9839-9678

${ }^{4}$ Universidade Federal de Lavras, Brasil. E-mail: samantaborges81@gmail.com Orcid ID: http://orcid.org/0000-0002-6803-1415
} 
frequentemente pela existência da venda, capela ou escola e cujo raio de ação marca os limites do bairro (Muller, 1966: 129).

Igualmente, Cândido (1968) destaca o sentimento de localidade e cooperação existente como compartilhados no território, considerando uma estrutura fundamental da sociabilidade, que é formada pelo agrupamento de algumas ou muitas famílias, e vinculada pela convivência, pelas práticas de auxílio mútuo e por atividades lúdicoreligiosas. Esse agrupamento de famílias é chamado de bairro, e é no mesmo bairro que se encontram o limite da cooperação e dos deveres (Cândido, 1968).

O que é bairro? - perguntei certa vez a um velho caipira, cuja resposta pronta exprime numa frase o que se vem expondo aqui: - Bairro é uma naçãozinha. Entenda-se: a porção da terra a que os moradores têm consciência de pertencer, formando uma certa unidade diferente das outras (Cândido, 1968: 65).

Os bairros rurais no sul de Minas Gerais, apesar de possuírem a essência apontada por Cândido (1968), possuem dinâmicas sociais distintas em relação a outros bairros do Estado, as quais podem ser medidas através de uma maior ou menor inserção dos fatores de influências externos como, por exemplo, a abrangência de políticas públicas, a influência do Estado, costumes urbanos, mercado industrial etc. Podemos citar desde a forma como os moradores utilizam a terra, passando pelo número de filhos, até a inserção de novas técnicas que auxiliam na lida do campo.

O bairro Peroba é uma localidade rural pertencente ao distrito de Lourenço Velho, também conhecido por distrito do Rio Manso, do município de Itajubá, localizado na região sul do estado de Minas Gerais (Minas Gerais, 1948). Em linha reta, a localidade fica bem próximo à sede do distrito (Rio Manso), cerca de 5,4km, mas, usando as estradas, fica a aproximadamente $29,8 \mathrm{~km}$. Em relação à sede municipal, o bairro se encontra $17 \mathrm{~km}$ distante. Está situado a mais de 1250 metros de altitude, na Serra da Mantiqueira, cercado pela Mata Atlântica, e acolhido por clima ameno na maior parte do ano, inclusive no verão, mas o inverno pode ser intenso em certos dias de julho.

O bairro recebeu este nome porque antigamente existiam ali muitas árvores de peroba que foram extraídas para abastecer os carvoeiros que faziam parte da economia local há mais de oitenta anos, sendo este um período aproximado, uma vez que se é baseado em relatos de um morador ancião nascido e criado no bairro, obtidos durante as visitas ao bairro. Há 50 anos, a localidade era chamada de Fumaça Preta, nome que 
muitos moradores fazem questão de esquecer, ou mesmo nem mencionar, por questões identitárias, visto que os carvoeiros lembram trabalho duro, mal pago e desprestigiado.

Os limites territoriais da Peroba são desde a vertente que faz a divisa com a reserva florestal do município e com os bairros rurais da Ilha, da Serra dos Toledos, do Ano Bom e do Rio Manso. Estes limites foram informados pelos próprios moradores, uma vez que não existem documentos suficientes nos órgãos públicos que apresentem essa informação, devendo ainda considerar que muitos documentos analisados não compreendem de fato a realidade observada, tratando-se de documentos antigos em que retratavam a Peroba como uma extensão do bairro Serra dos Toledos.

A localidade possui água em abundância, devido às inúmeras nascentes que brotam de suas terras e que são usadas para abastecer o sistema hídrico de Itajubá. De acordo com um morador, cerca de quase metade de toda água usada pelos itajubenses que vivem na área urbana vem das nascentes da Peroba. O bairro também é atendido com energia elétrica e a maior parte dos moradores tem acesso à internet e serviços de telefonia celular, embora a rede convencional de celular funcione somente em determinados pontos. Uma vez ao mês, há visita de médicos que acontece na antiga escola.

No bairro há grande presença de produção agropecuária predominantemente familiar e, economicamente, sua população vive da comercialização dos itens que são frutos dessa organização familiar, através da produção de alfaces, repolhos, brócolis, tomates, cenouras, bananas, couves, cebolas, laranjas, ervas entre outros, através do sistema de hortas, orgânicas ou convencionais, das agroindústrias e da criação de gado leiteiro para a venda de leite e queijos. A comercialização desses produtos é realizada em feiras locais, supermercados, restaurantes, hotéis e através do Programa Nacional de Alimentação Escolar (PNAE).

Composto por 39 famílias, o bairro apresenta características de uma comunidade de parentesco, compartilhando um conjunto de memórias do passado, com fortes laços de cooperação, solidariedade, religioso e, sobretudo, laços de parentesco. Um bom exemplo sobre laços comunitários é a cooperação não no sentido de organização em torno de uma cooperativa, mas sim na necessidade de cooperar entre vizinhos nas atividades do campo, como a troca de dia de trabalho onde um ajuda na lavoura de outro e depois acontece a troca. O mutirão também é um outro exemplo em que os 
agricultores se juntam para realizarem a produção de compostos orgânicos para a lavoura ou quando surge a necessidade de reforma das casas, principalmente telhados, ou do centro comunitário.

Outro aspecto marcante na localidade é a intensa religiosidade católica, representada por Santa Rita de Cássia, a padroeira da comunidade, homenageada no mês de março ou abril com novenas, missas e quermesses que ganham vida graças à atuação comunitária de seus moradores. O bairro possui uma igreja, considerada símbolo religioso e arquitetônico da localidade, em que todas as festividades acontecem tanto em torno do calendário litúrgico quanto para outros eventos que corroboram para arrecadação de fundos usados para a sua manutenção. A missa é o principal evento, depois das festas comemorativas, que proporciona o encontro semanal entre os moradores do bairro, e que acontece todo penúltimo domingo de cada mês.

As fotografias que contemplam este ensaio estão divididas em temas que indicam uma sequência de apresentação, assim como foi feito neste texto, iniciando pelas fotos que mostram a configuração do bairro - seu relevo, casas, estradas, cercas, pastos e matas - diante o olhar do visitante que chega ao local pela primeira vez e, depois, lhe é apresentado a rotina deste universo - trabalho, convivência, festejos, costumes e a relação das pessoas com a natureza. Os registros foram realizados entre junho de 2018 e setembro de 2019 e fazem parte de acervo fotográfico montado durante uma pesquisa de mestrado realizada no bairro. 


\section{REFERÊNCIAS}

CÂNDIDO, Antônio. Os parceiros do Rio Bonito: estudo sobre o caipira paulista e a transformação dos seus meios de vida. $1^{\circ}$ ed. rev. São Paulo: Edusp, 1968.

IBGE - INSTITUTO BRASILEIRO DE GEOGRAFIA E ESTATÍSTICA. Pesquisa nacional por amostra de domicílios: síntese de indicadores 2015. Coordenação de Trabalho e Rendimento. Rio de Janeiro: IBGE, 2016. Disponível em: < https://biblioteca.ibge.gov.br/visualizacao/livros/liv98887.pdf > Acesso em: $07 \mathrm{fev}$. 2020 .

. Censo demográfico 1991: resultados do universo relativos às características da população e dos domicílios. Rio de Janeiro: IBGE, 1992. Disponível em: $<$ https://biblioteca.ibge.gov.br/visualizacao/periodicos/82/cd_1991_n1_caracteristicas_p opulacao_domicilios_br.pdf $>$ Acesso em: 08 mar. 2020.

MINAS GERAIS. Lei Estadual No 336 de 27/12/1948. Estabelece a divisão administrativa e judiciária do Estado, a vigorar de $1^{\circ}$ de janeiro de 1949 a 31 de dezembro de 1953, e dá outras providencias. Disponível em: < https://www.almg.gov.br/consulte/legislacao/ completa/completa-novamin.html?tipo=Lei\&num=336\&ano=1948> Acesso em: 08 mai. 2020.

MULLER, Nice Lecocq. Bairros Rurais do Município de Piracicaba/SP. In Boletim Paulista de Geografia. São Paulo, n. 43, julho/1966, p. 83-130.

Recebido: 22/05/2020

Aprovado: 04/09/2020 


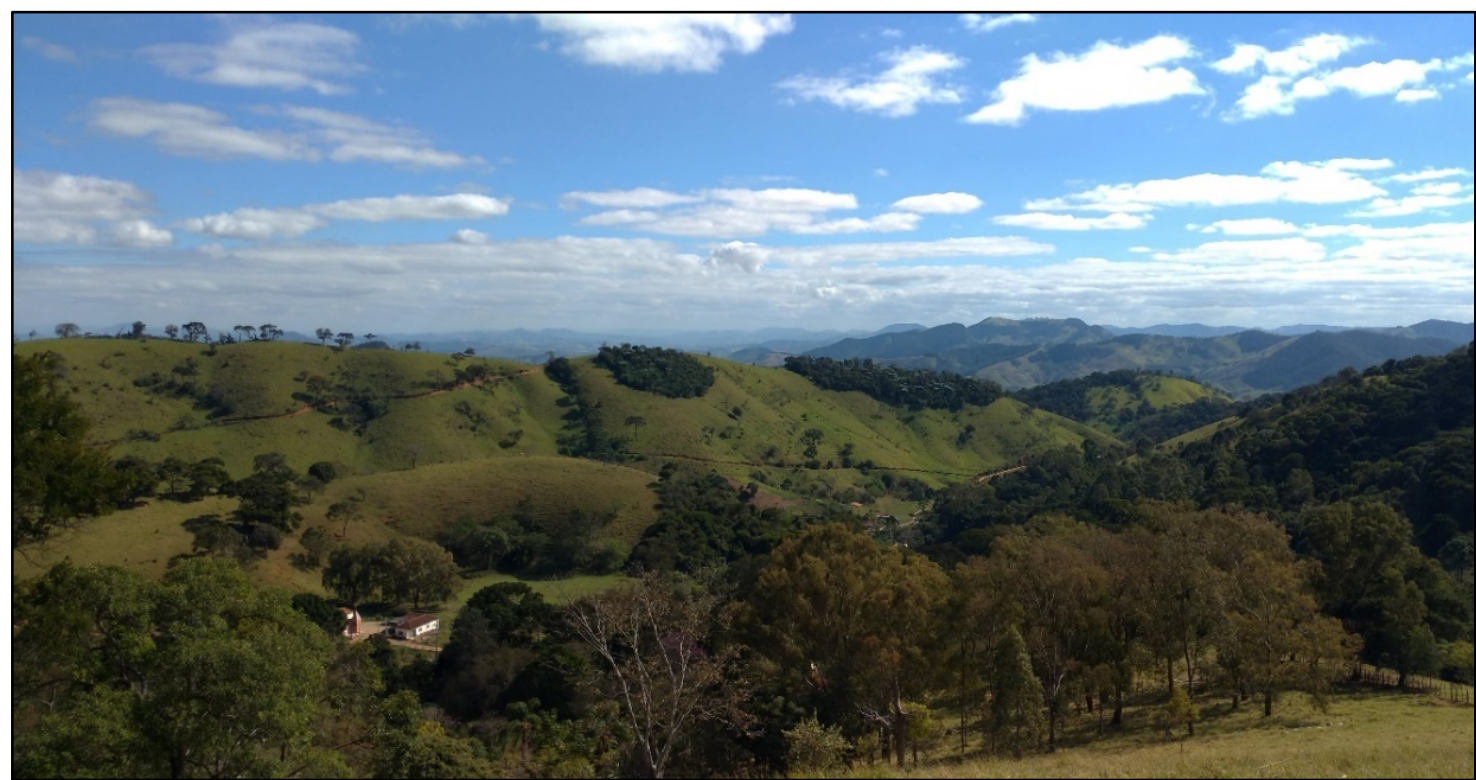

Fotografia 1: Vista panorâmica da paisagem da Peroba.

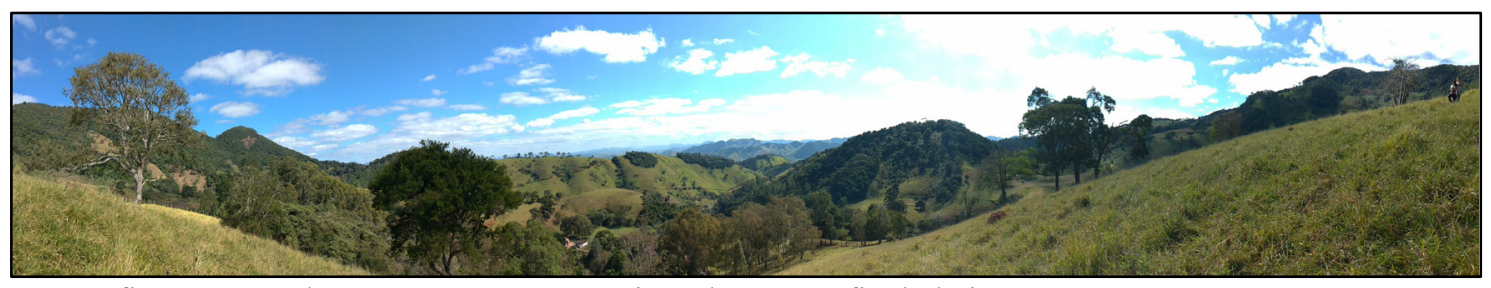

Fotografia 2: Montanhas e morros característicos da topografia do bairro.

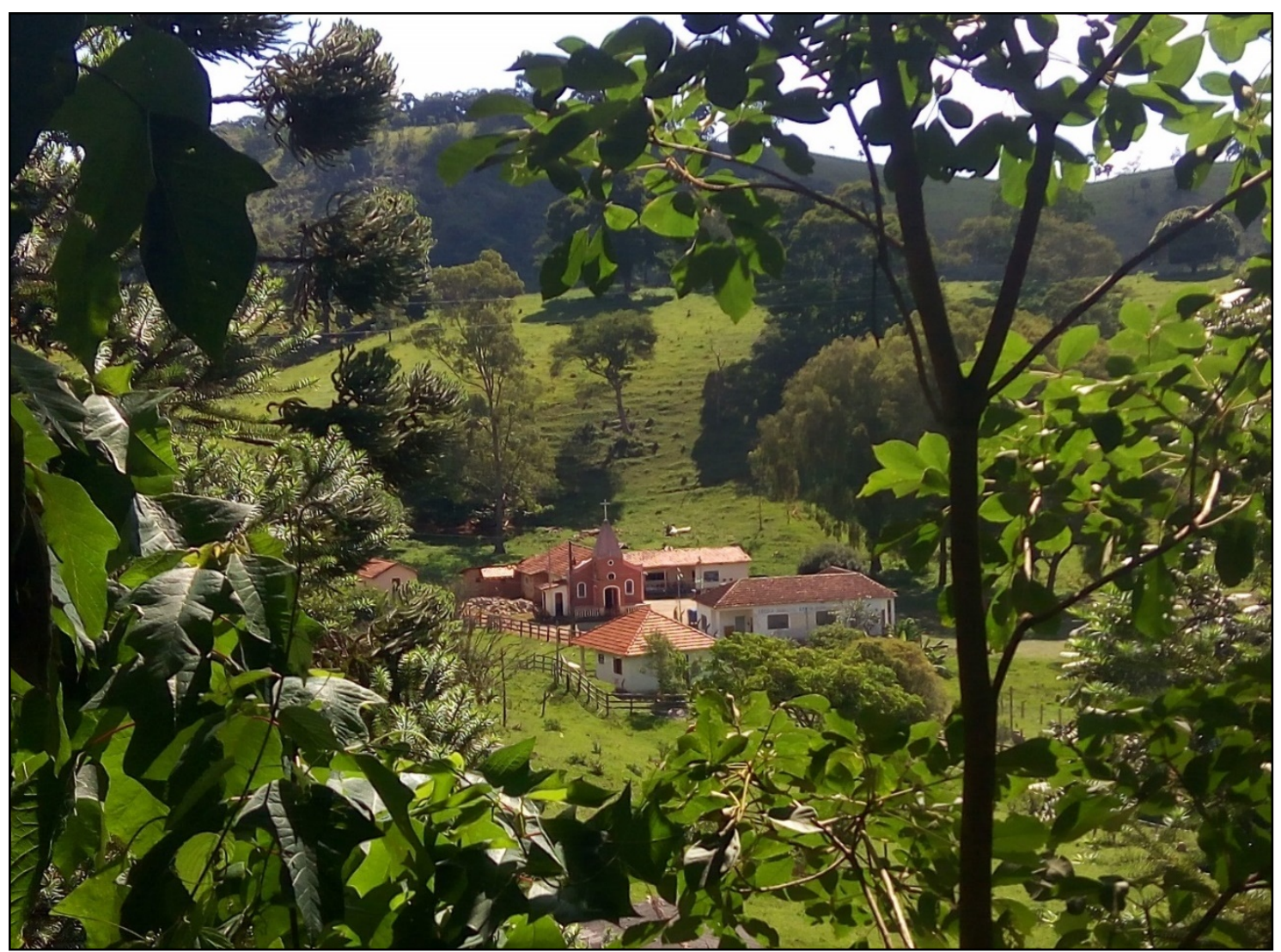

Fotografia 3: Centro comunitário - igreja, antiga escola, bar, salão e cozinha comunitária. 


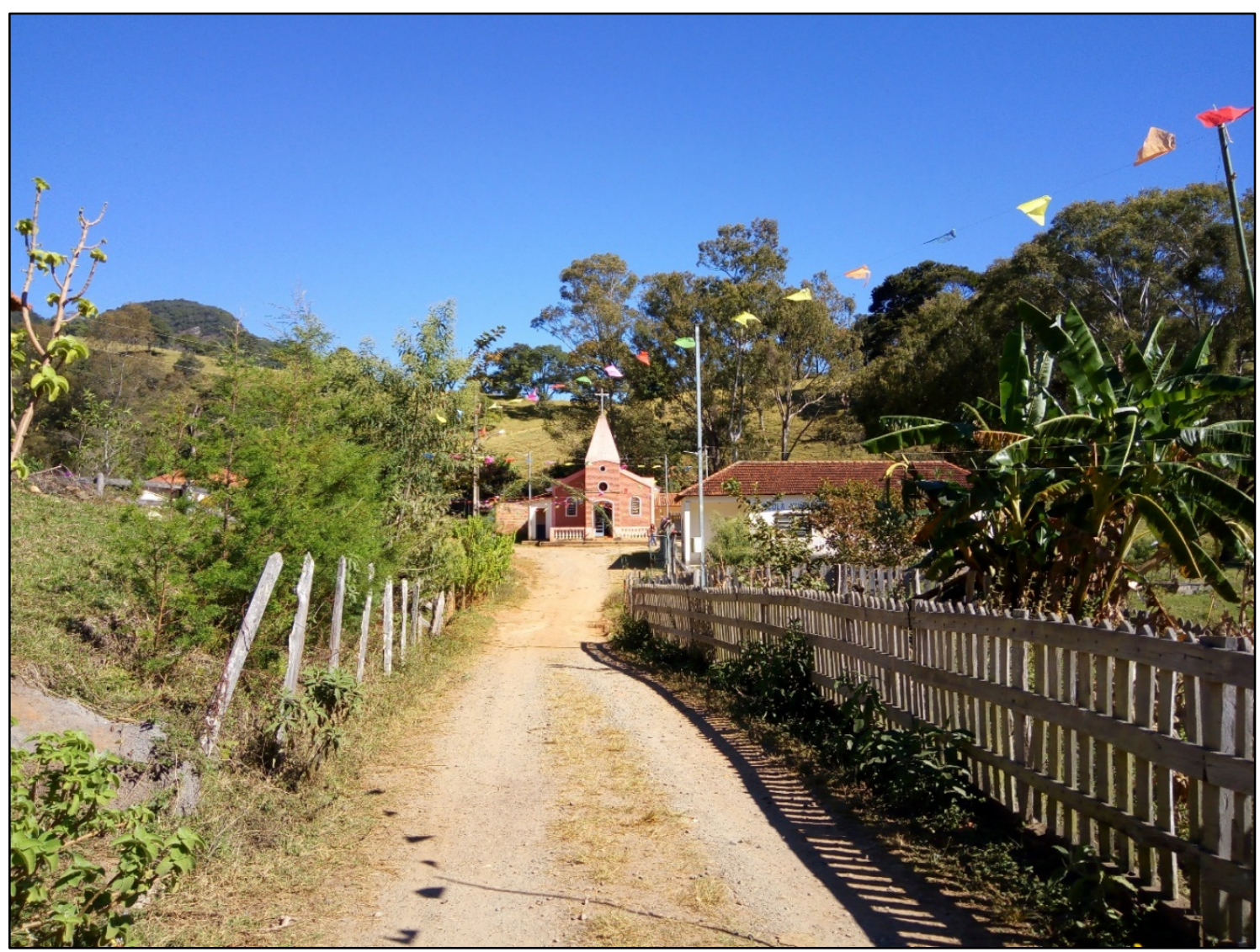

Fotografia 4: Via de acesso principal ao centro comunitário do bairro.

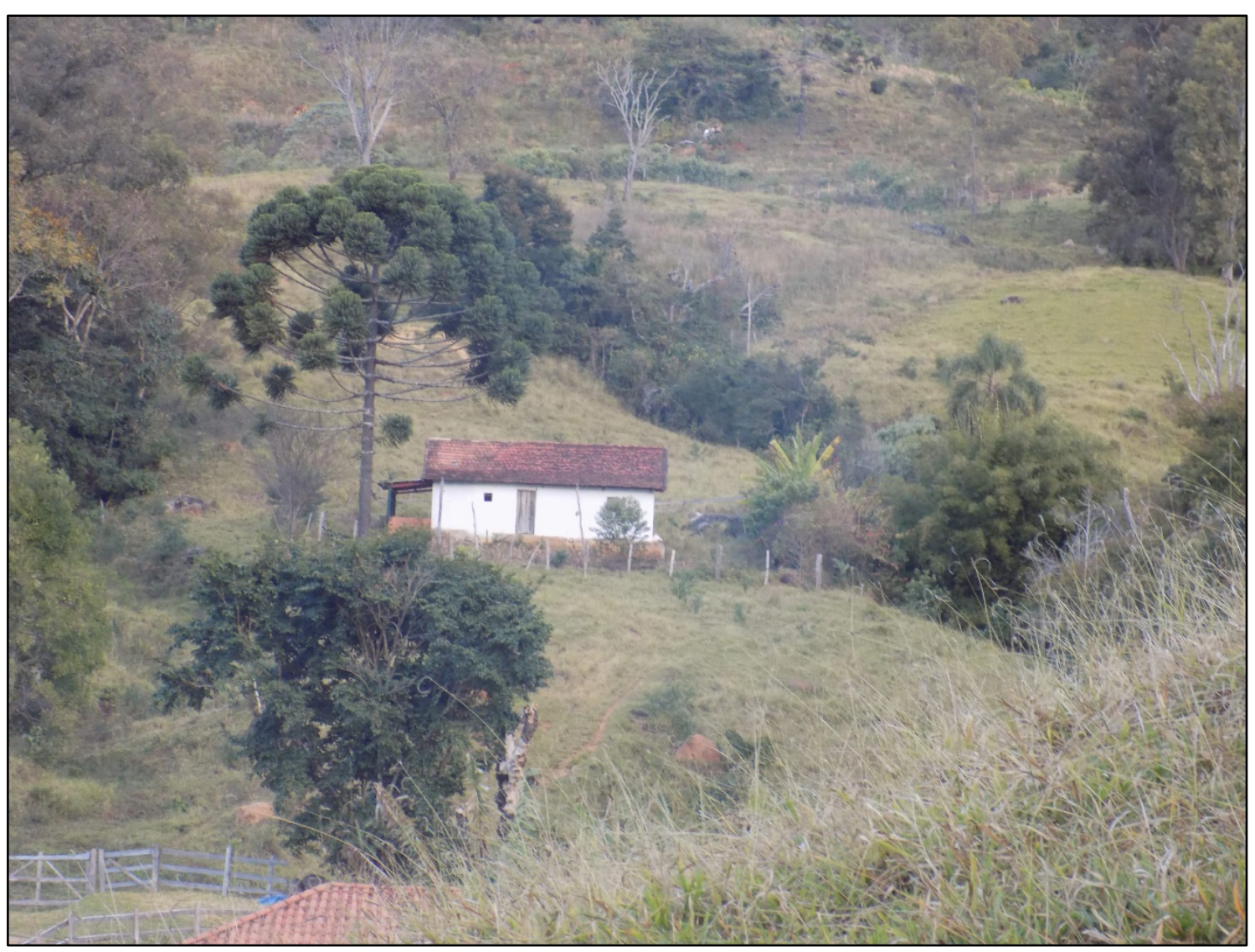

Fotografia 5: Casa com arquitetura típica do bairro. 


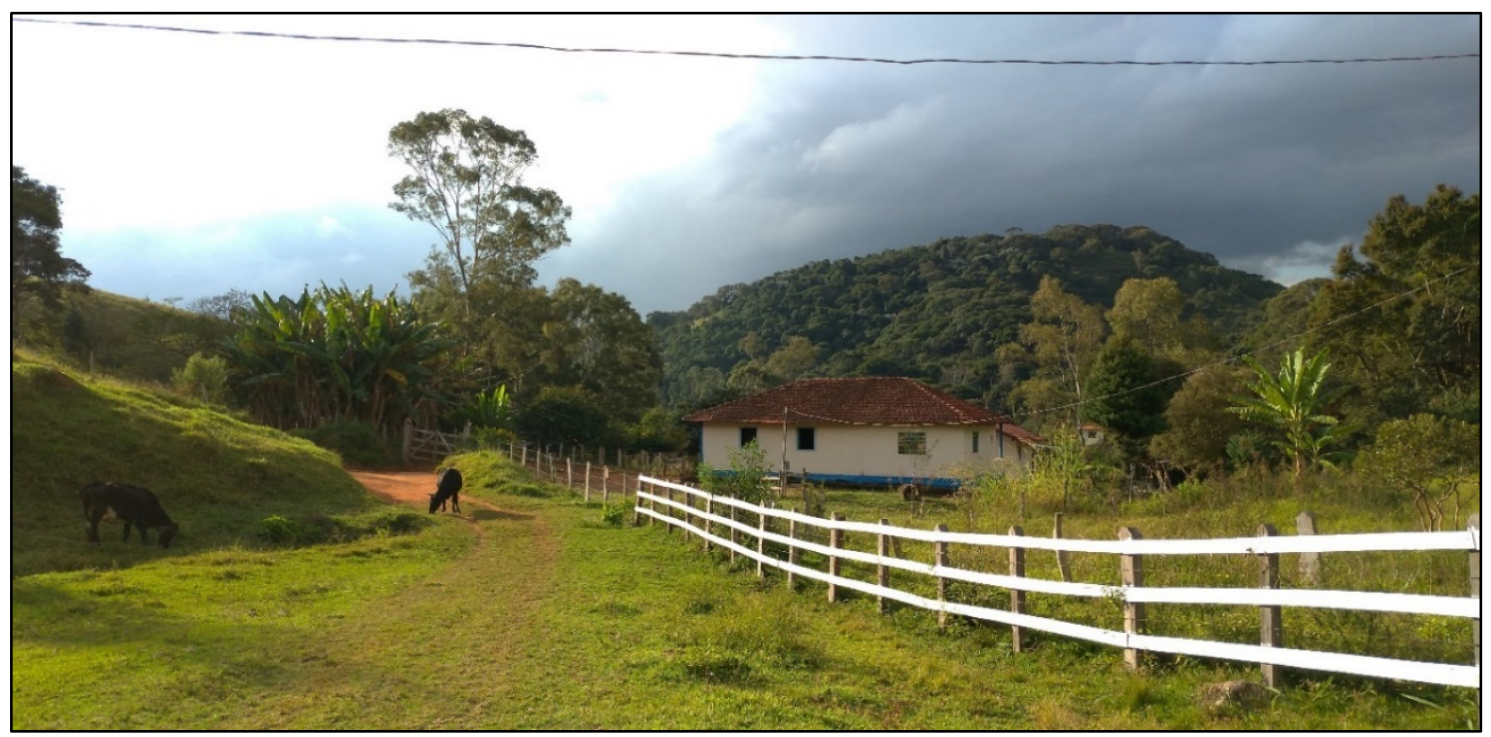

Fotografia 6: Montanhas, moradia e pastagem característica do lugar.

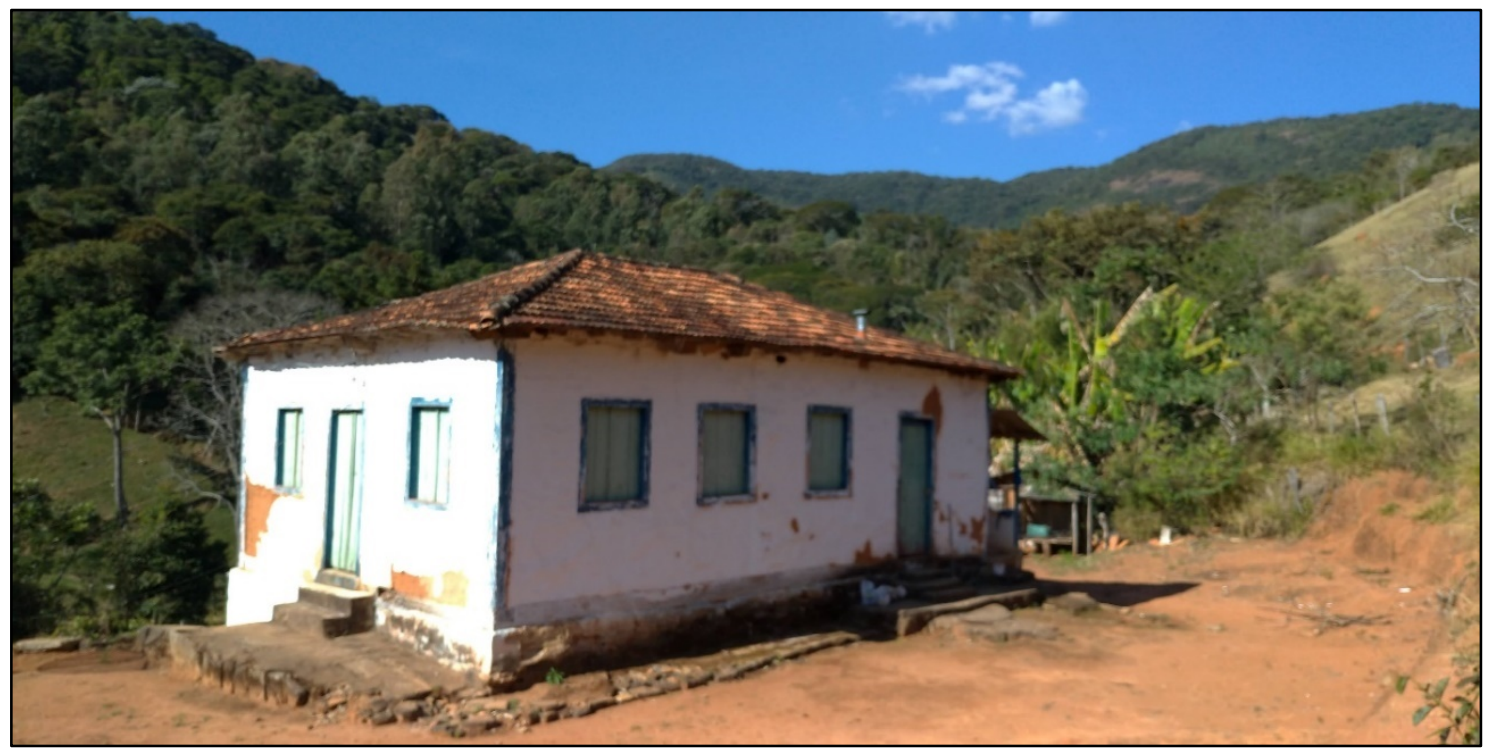

Fotografia 7: Casa do final do século XIX construída em pau-a-pique.

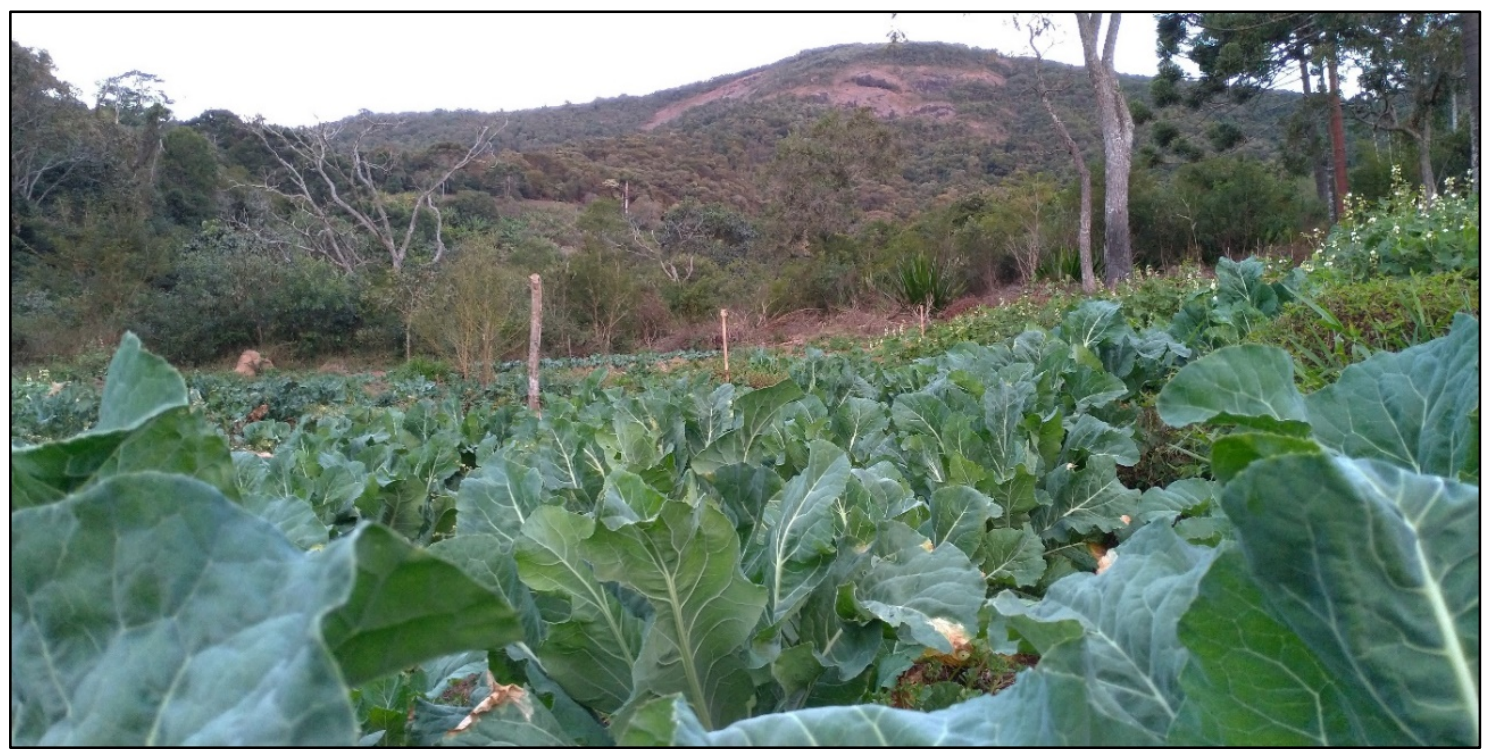

Fotografia 8: Plantação de couve-flor. 


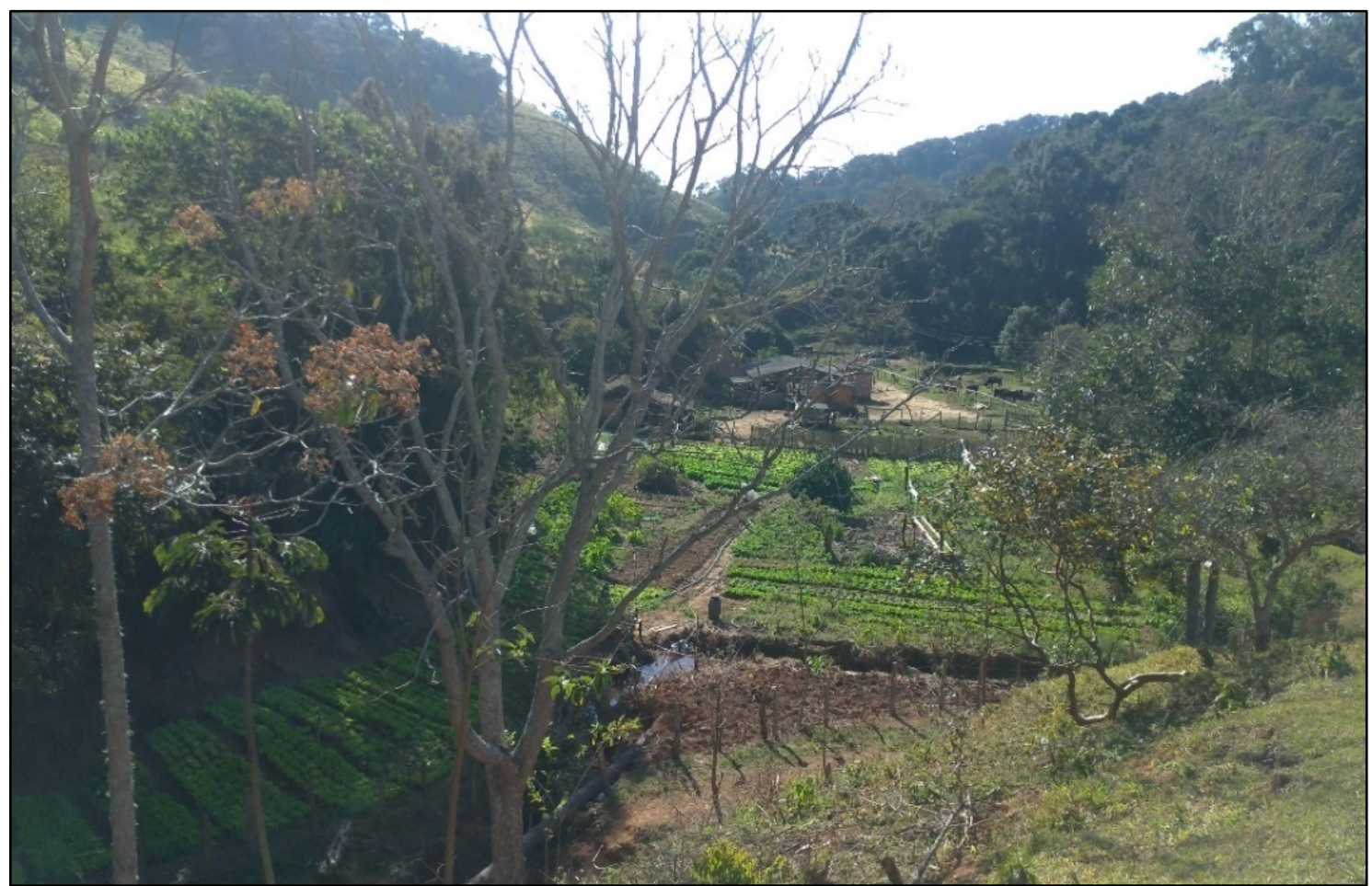

Fotografia 9: Horta de um agricultor famoso pelos belos pés de alfaces.

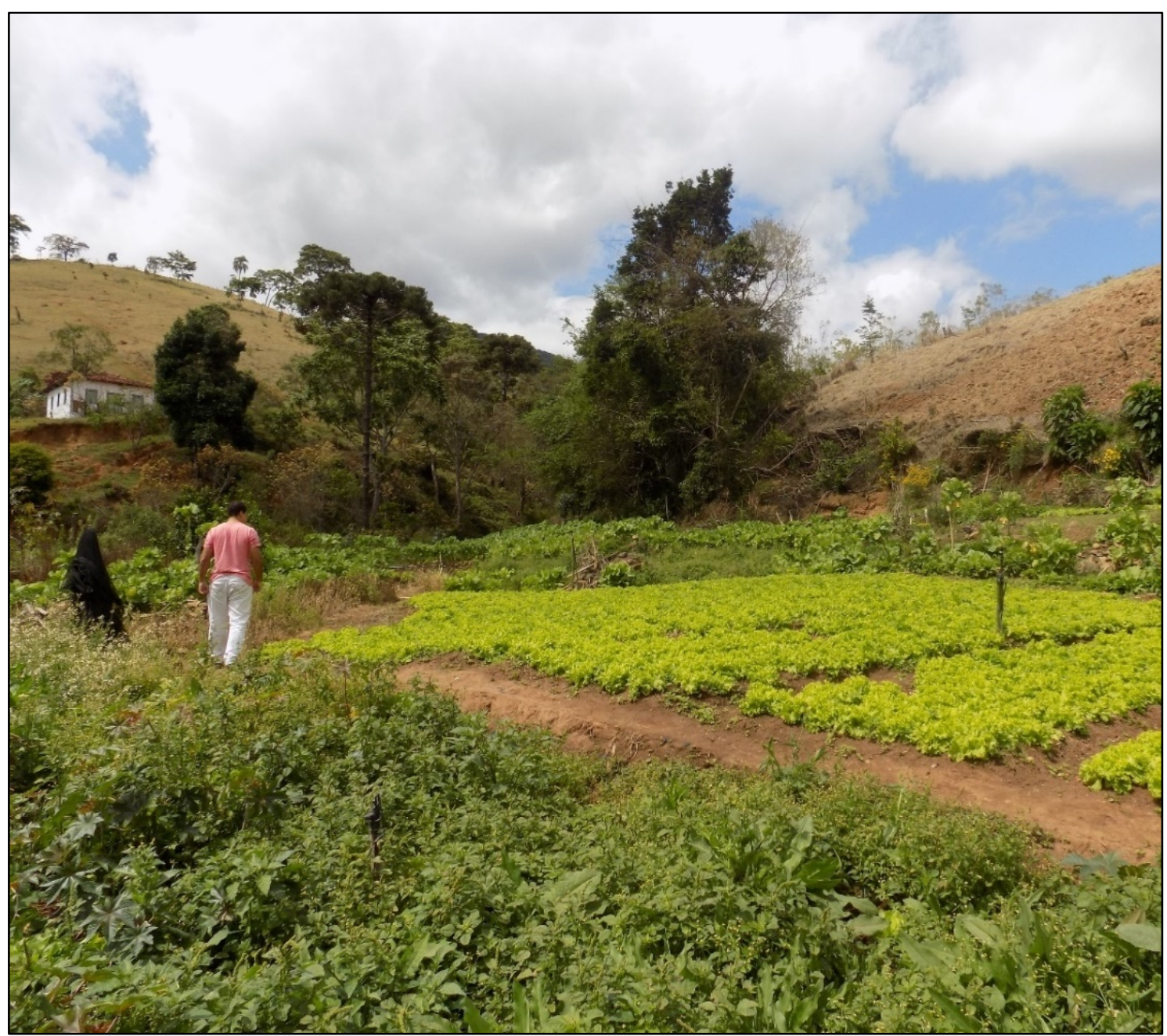

Fotografia 10: Plantação de alface - o cultivo das hortas é uma garantia de sustento e renda. 


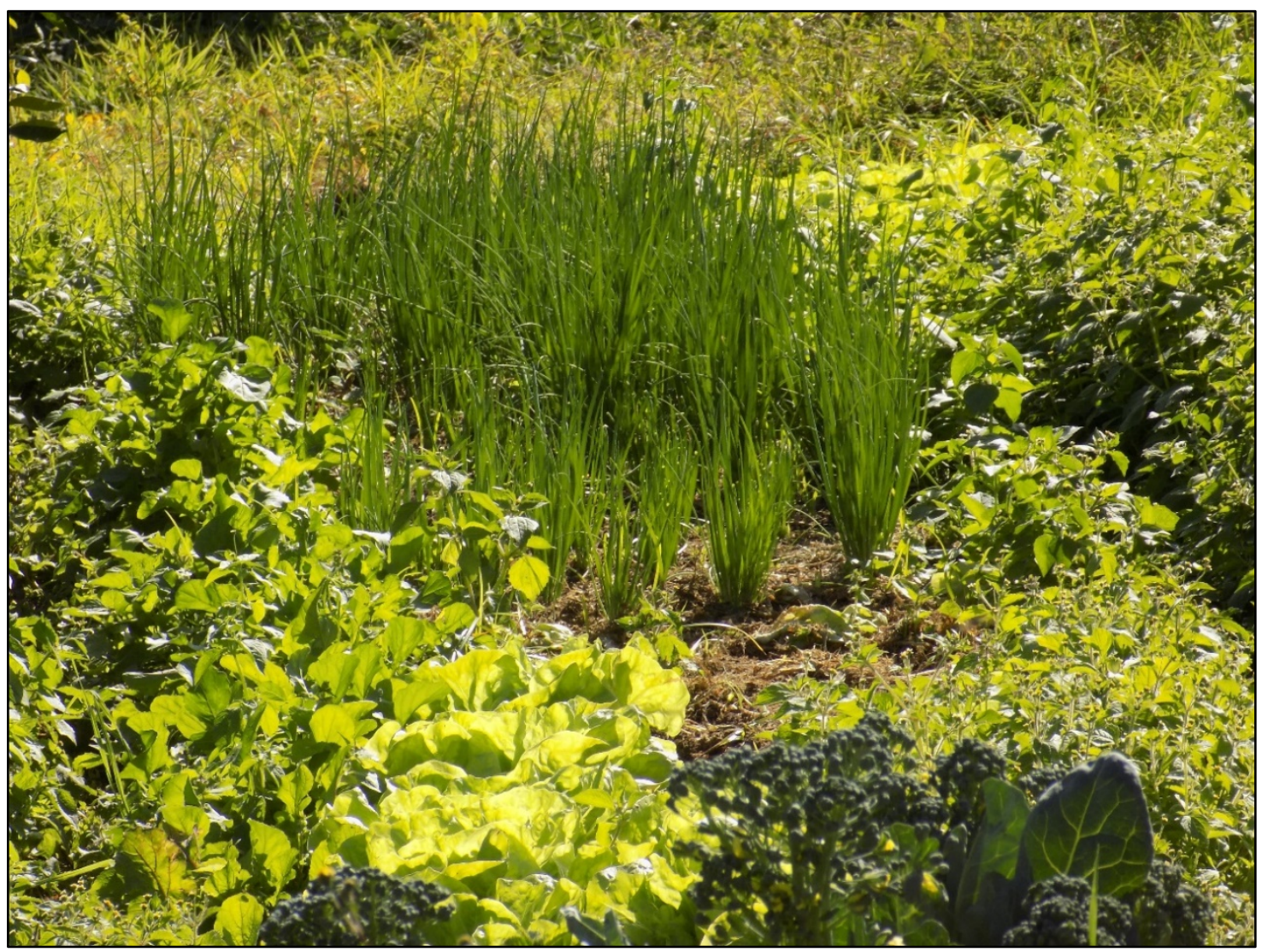

Fotografia 11: Horta de temperos verdes.

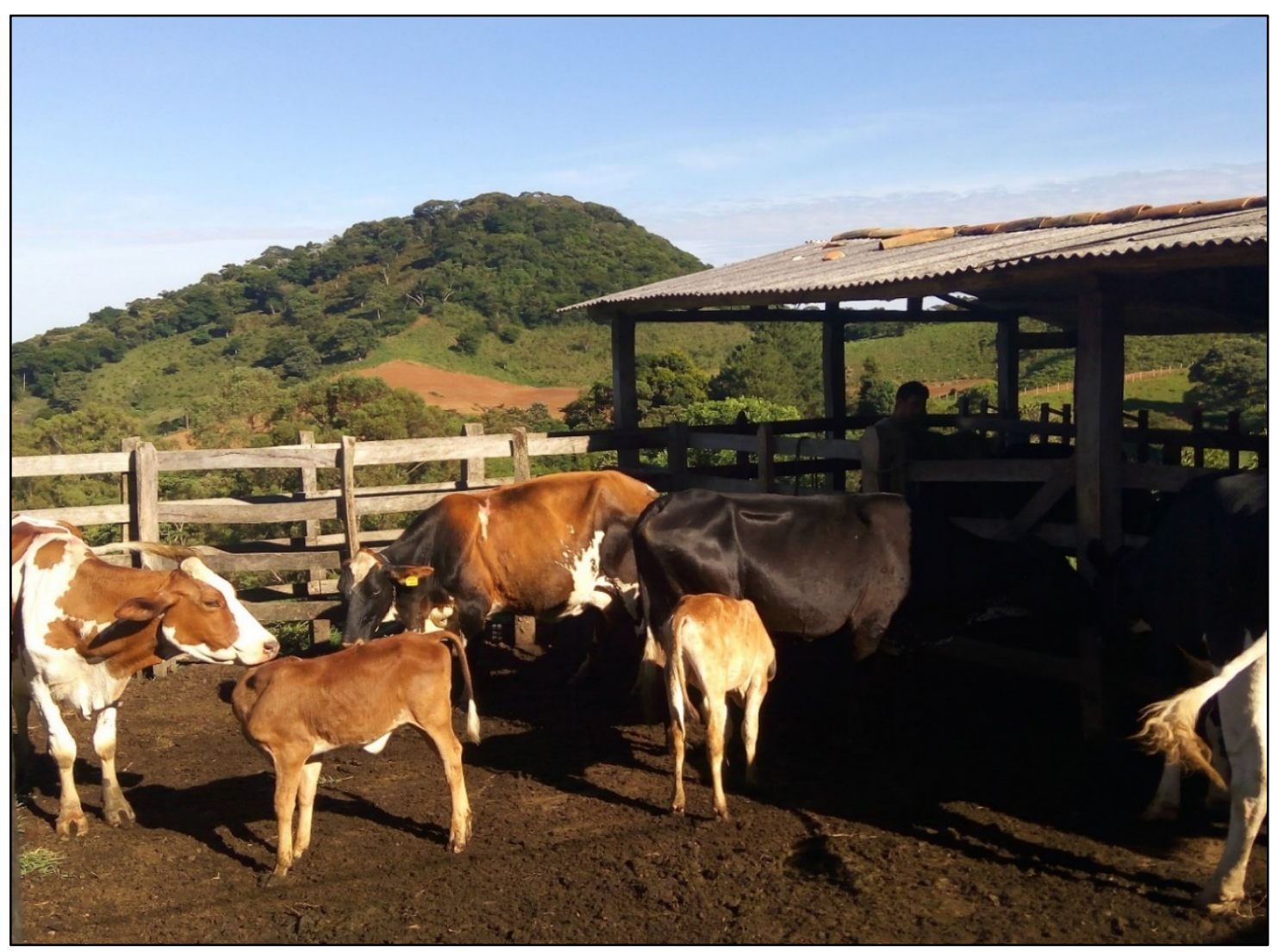

Fotografia 12: Curral de ordenha - leite e produção de queijos fazem parte da economia do bairro. 


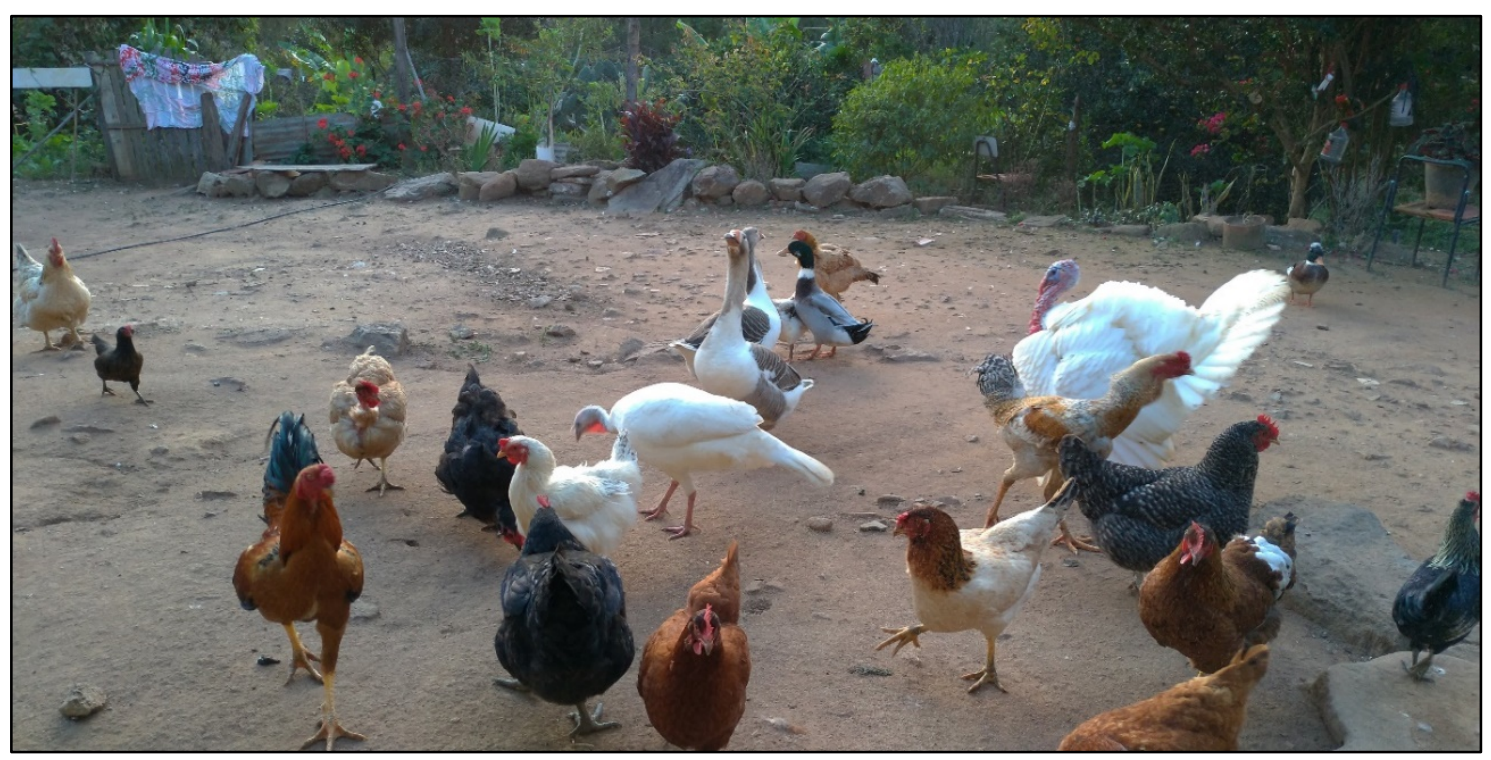

Fotografia 13: Criação de aves caipiras para comercialização de ovos nas feiras.

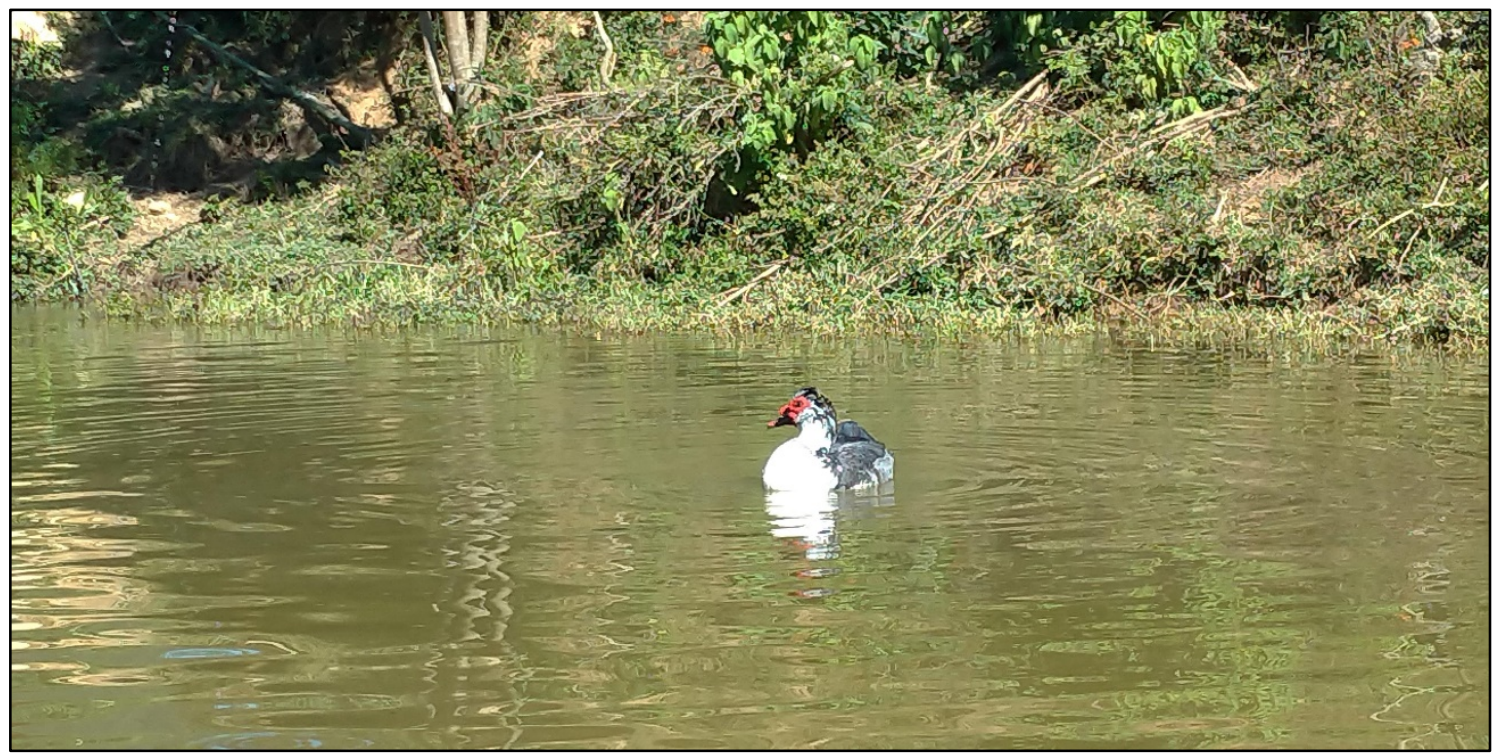

Fotografia 14: Pato - ave doméstica típica da vida caipira.

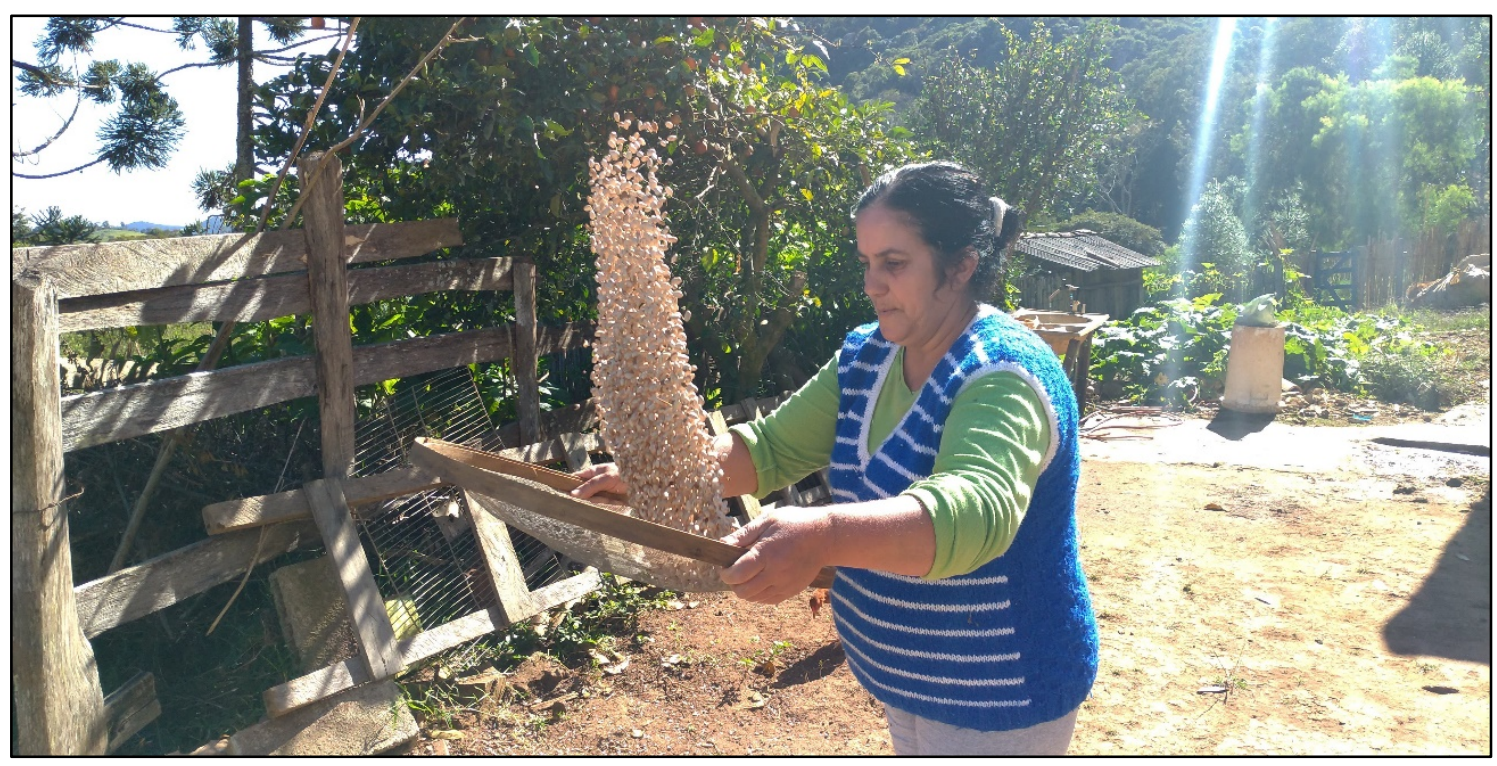

Fotografia 15: Agricultora Vanilda peneirando feijão para retirar os ciscos. 


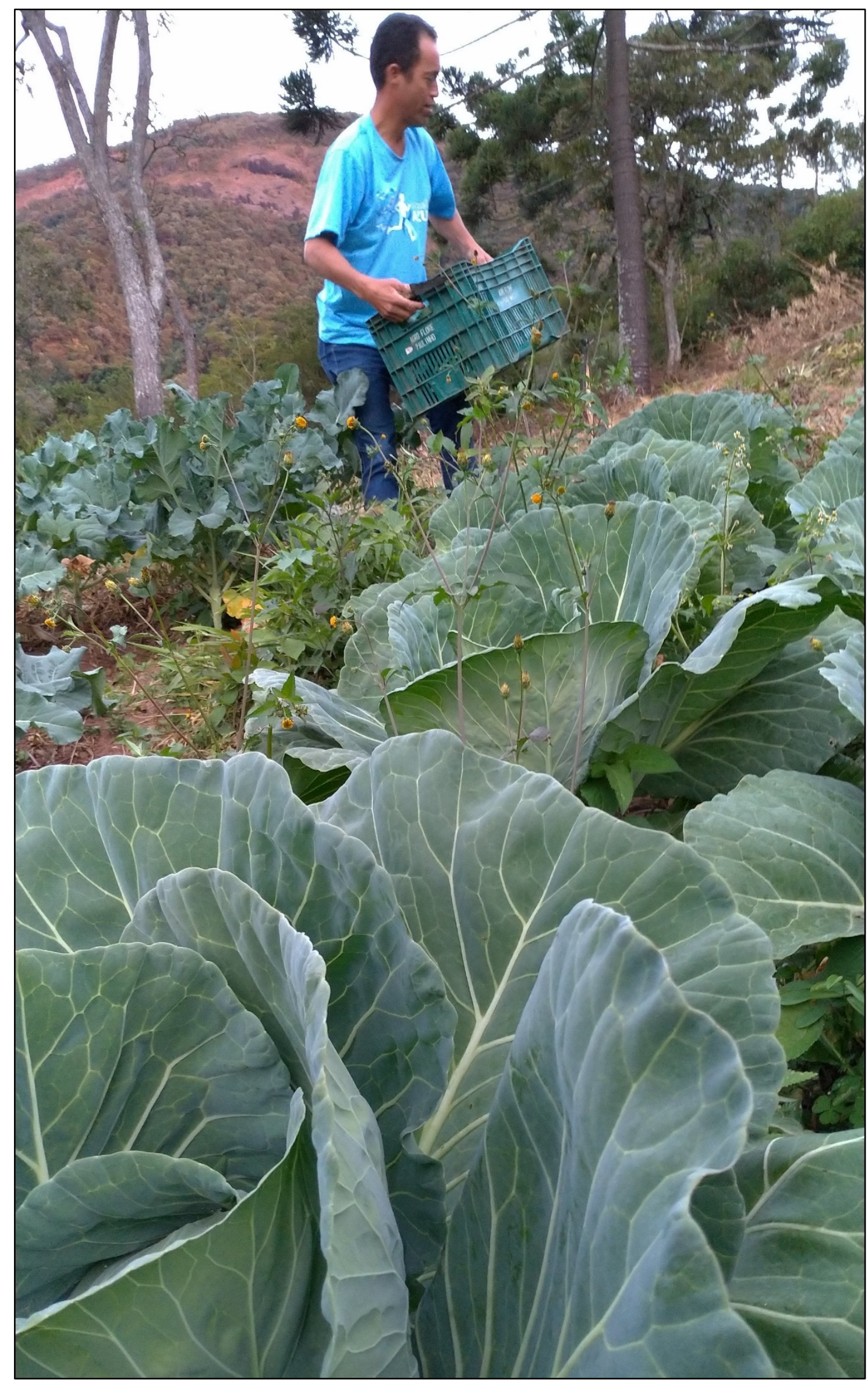

Fotografia 16: Agricultor Ednilson colhendo couve-flor e brócolis para vender na feira.

Iluminuras, Porto Alegre, v. 21, n. 54, p. 890-906, setembro, 2020. 


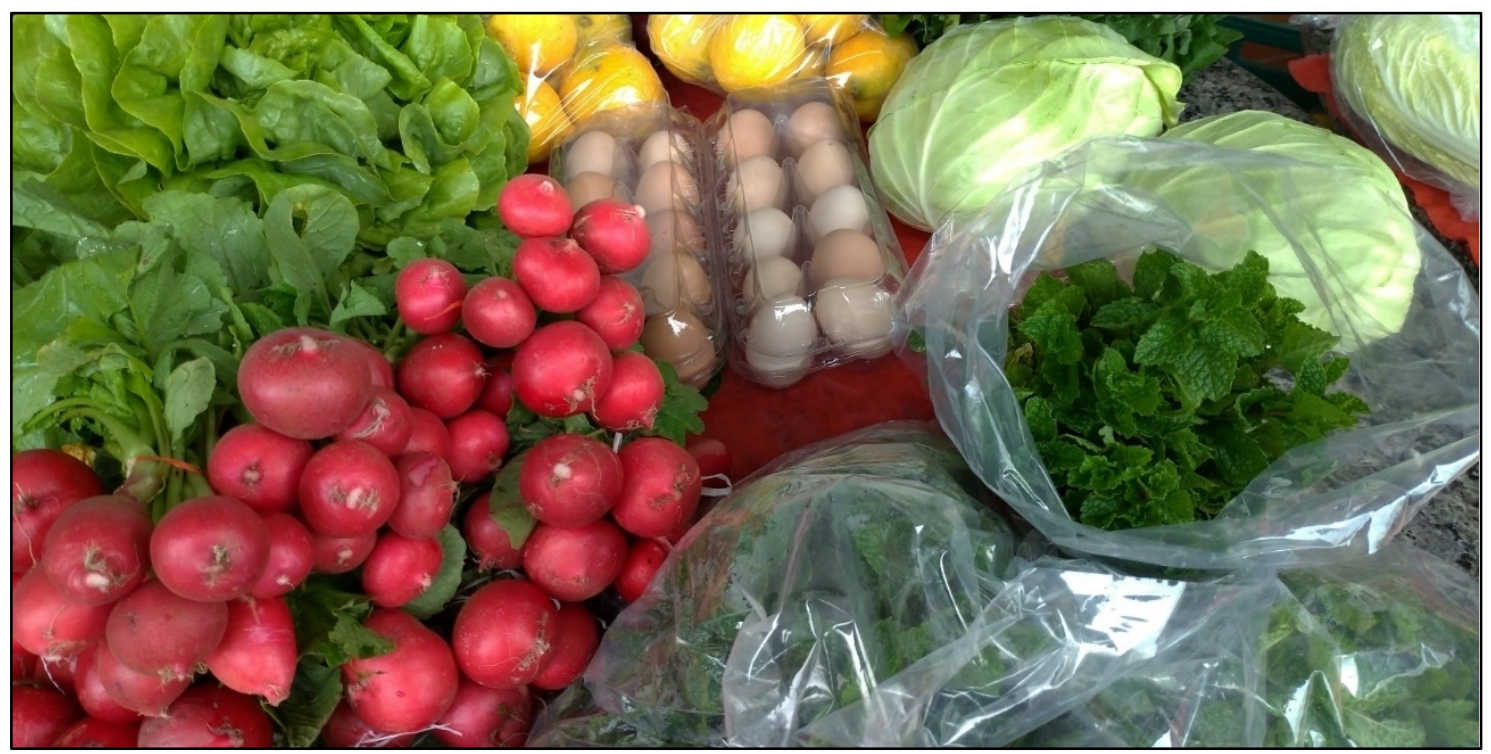

Fotografia 17: Produtos agroecológicos comercializados na feira de Itajubá.

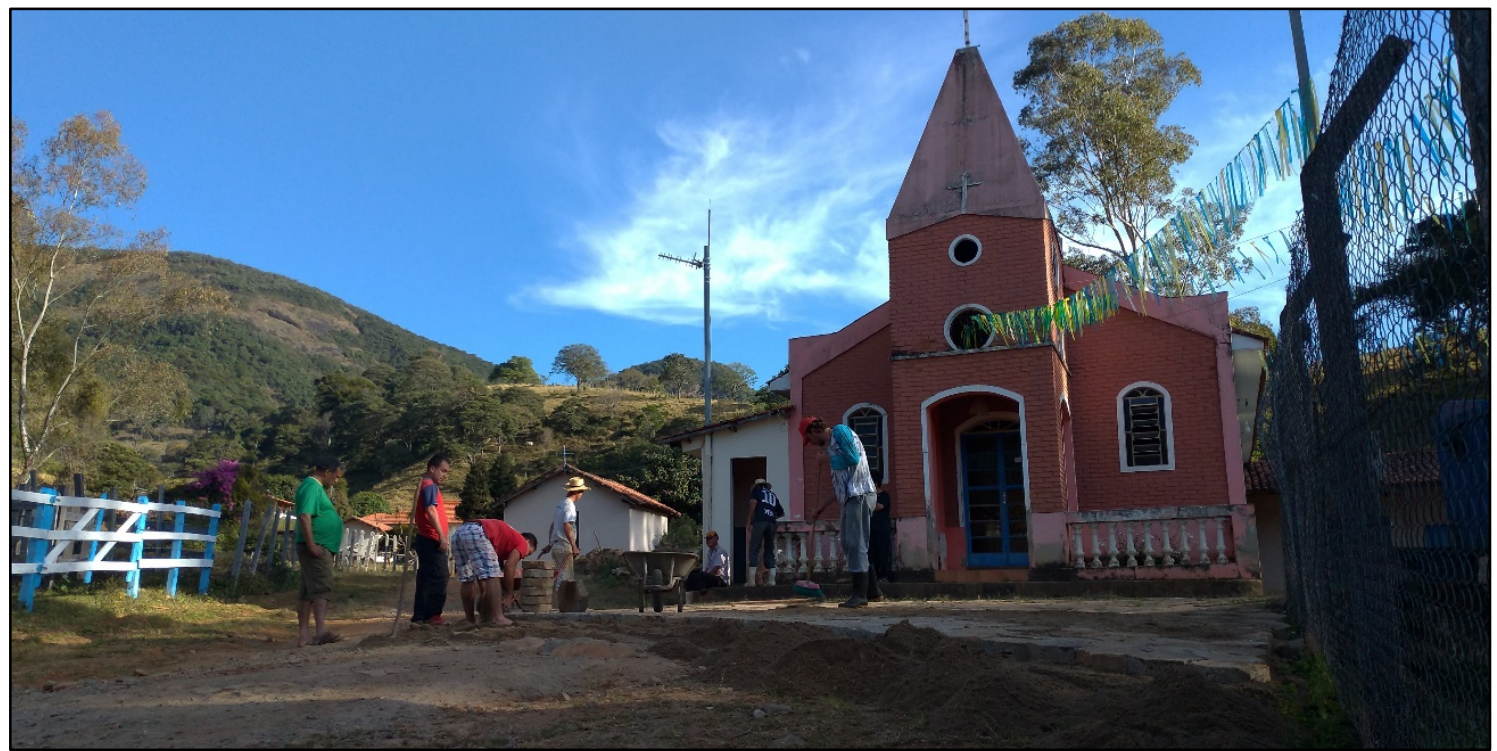

Fotografia 18: Mutirão para o calçamento do pátio da Igreja de Santa Rita de Cássia.

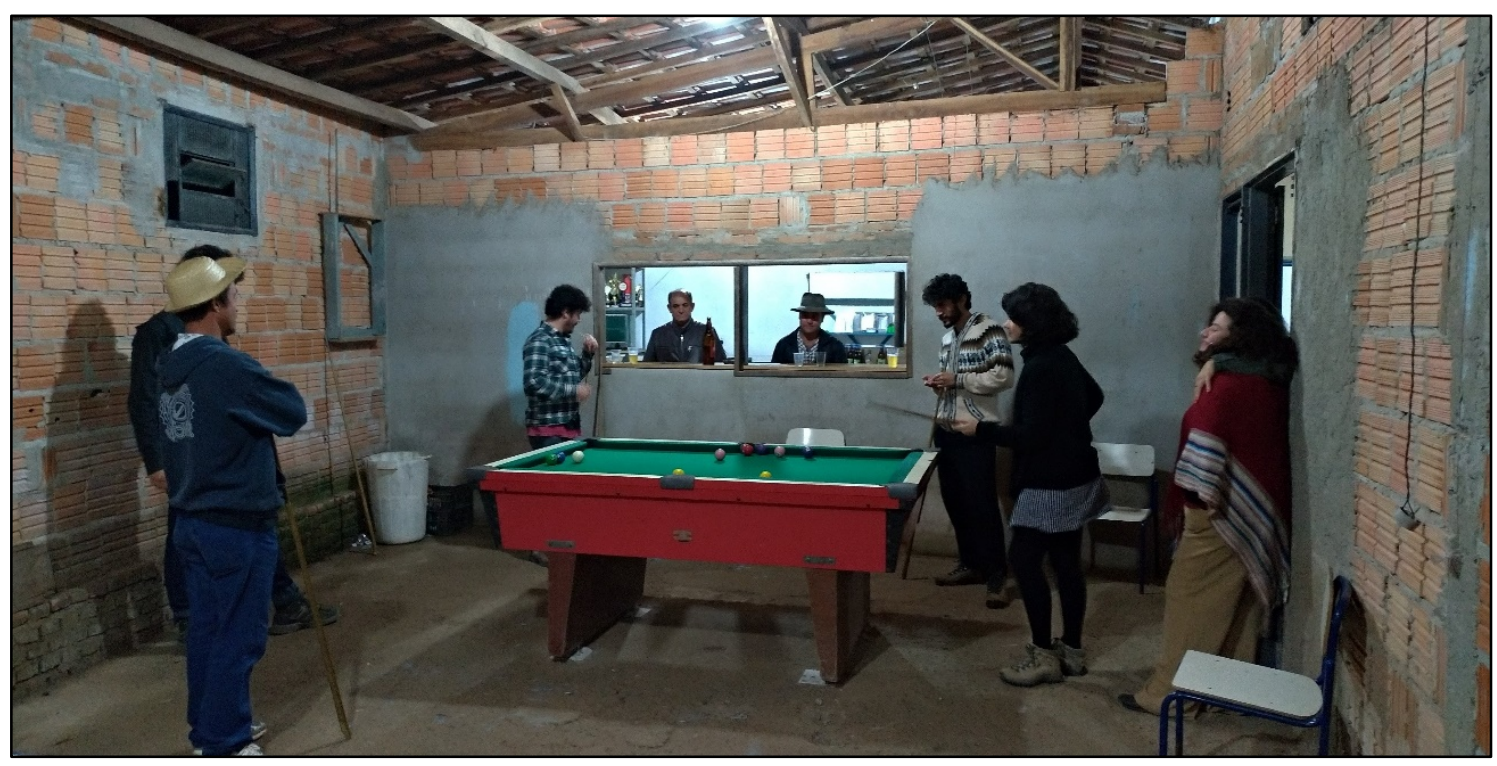

Fotografia 19: Bar de encontro nos fins de semana e festas.

Iluminuras, Porto Alegre, v. 21, n. 54, p. 890-906, setembro, 2020. 


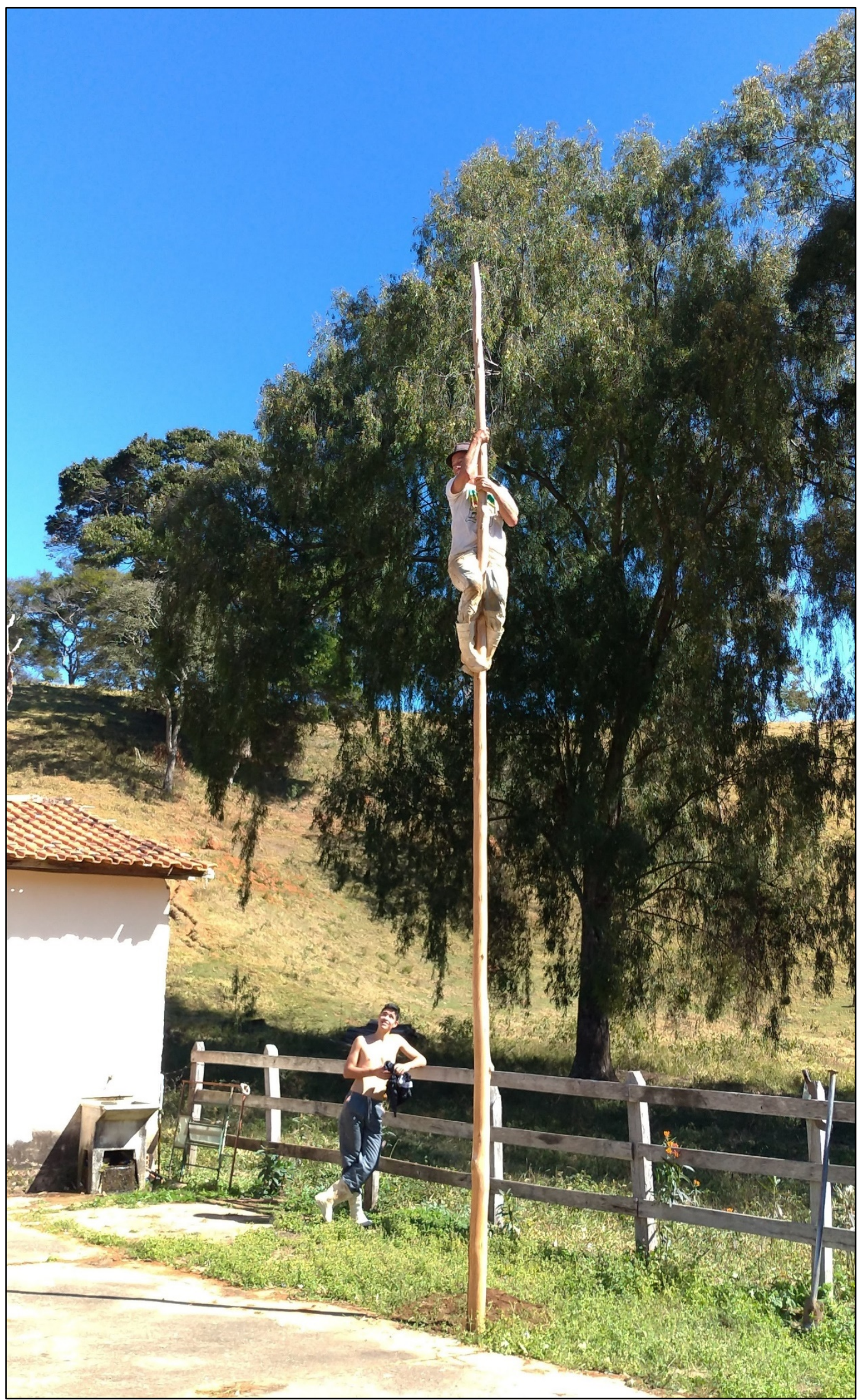

Fotografia 20: Brincadeira do pau-de-sebo na festa junina, em 2019.

Iluminuras, Porto Alegre, v. 21, n. 54, p. 890-906, setembro, 2020. 


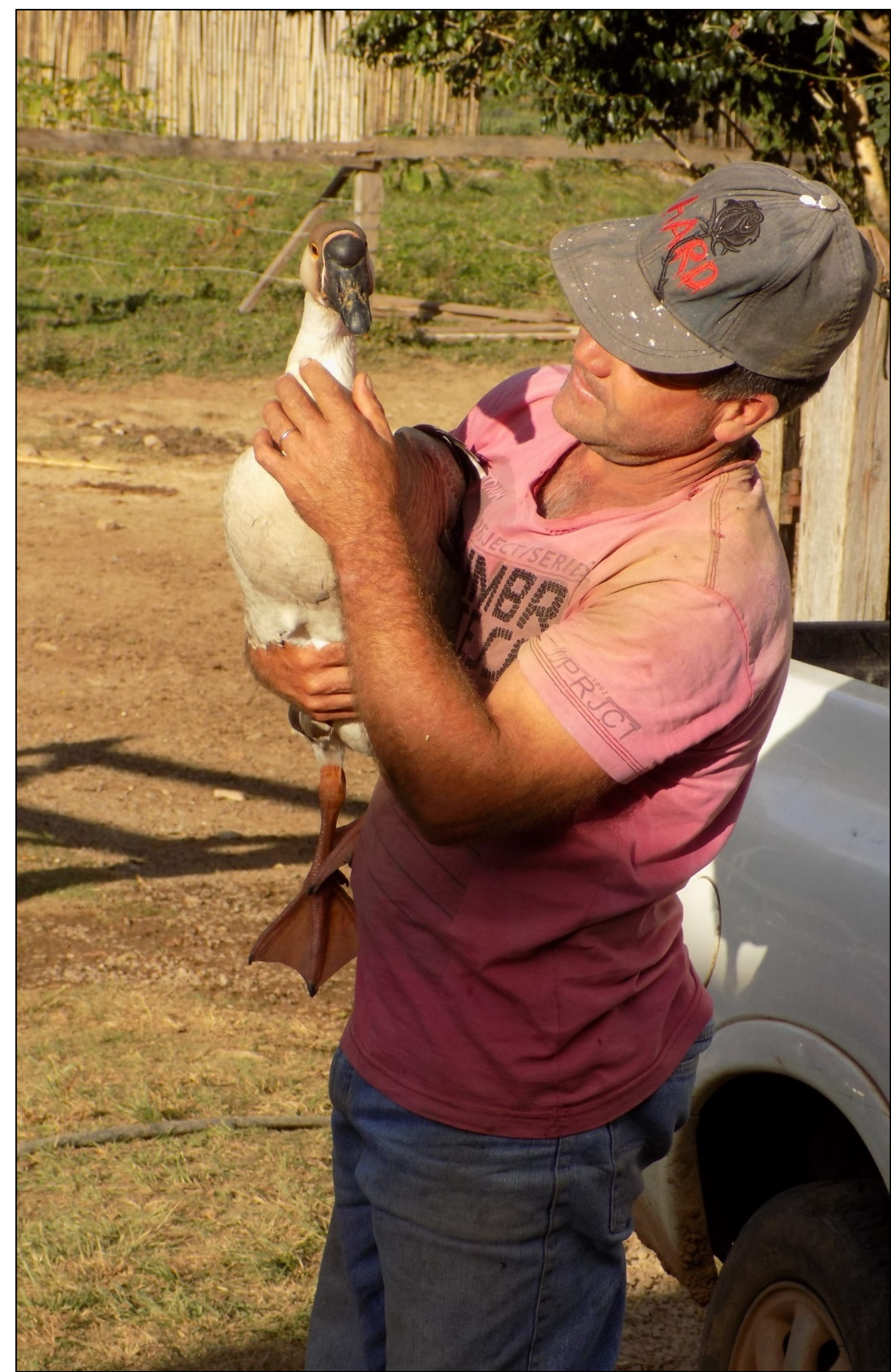

Fotografia 21: Agricultor Romildo e seu ganso - a ave é comum na vida rural para a proteção das casas. 


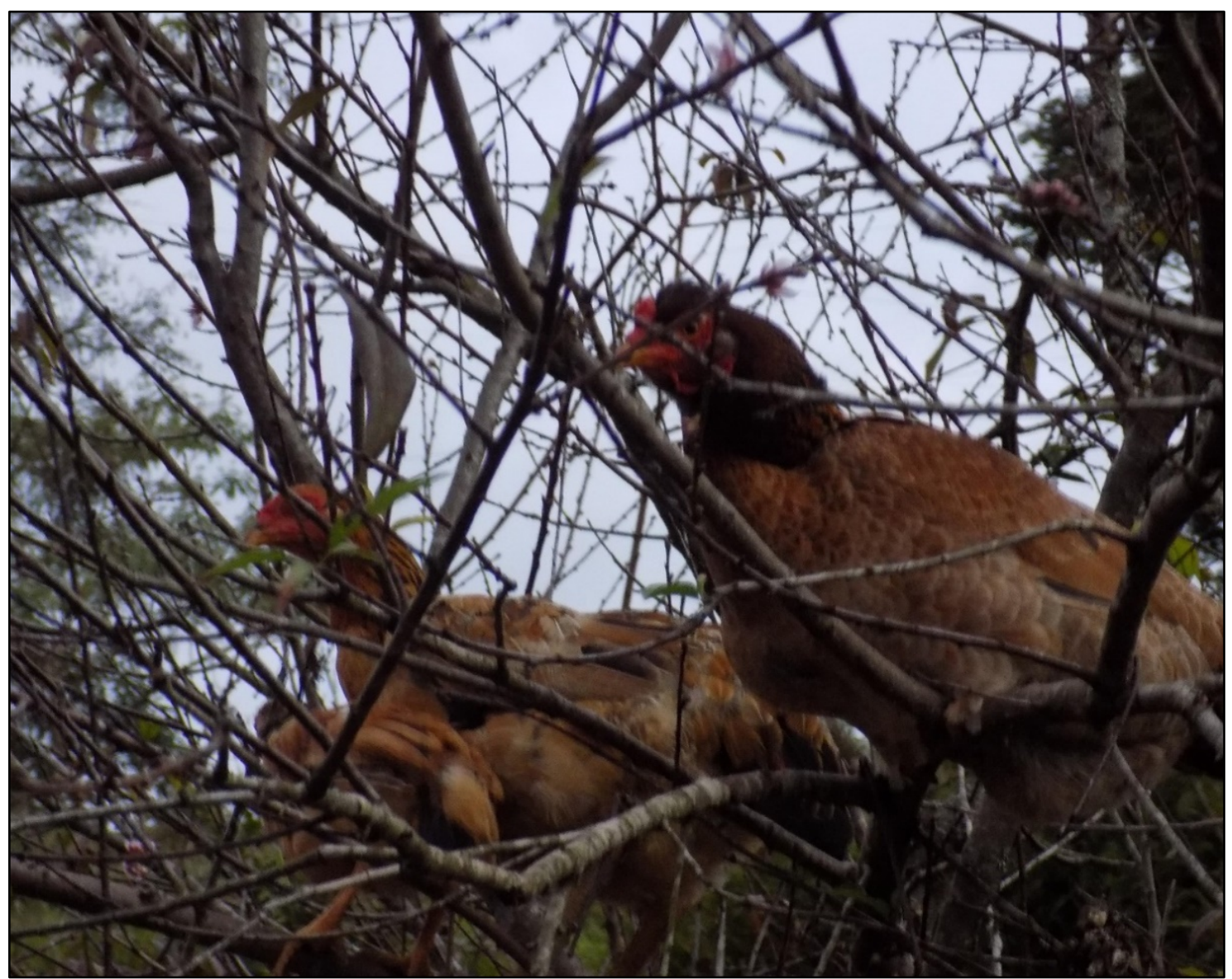

Fotografia 22: Galinhas empoleiradas nas árvores no cair da tarde.

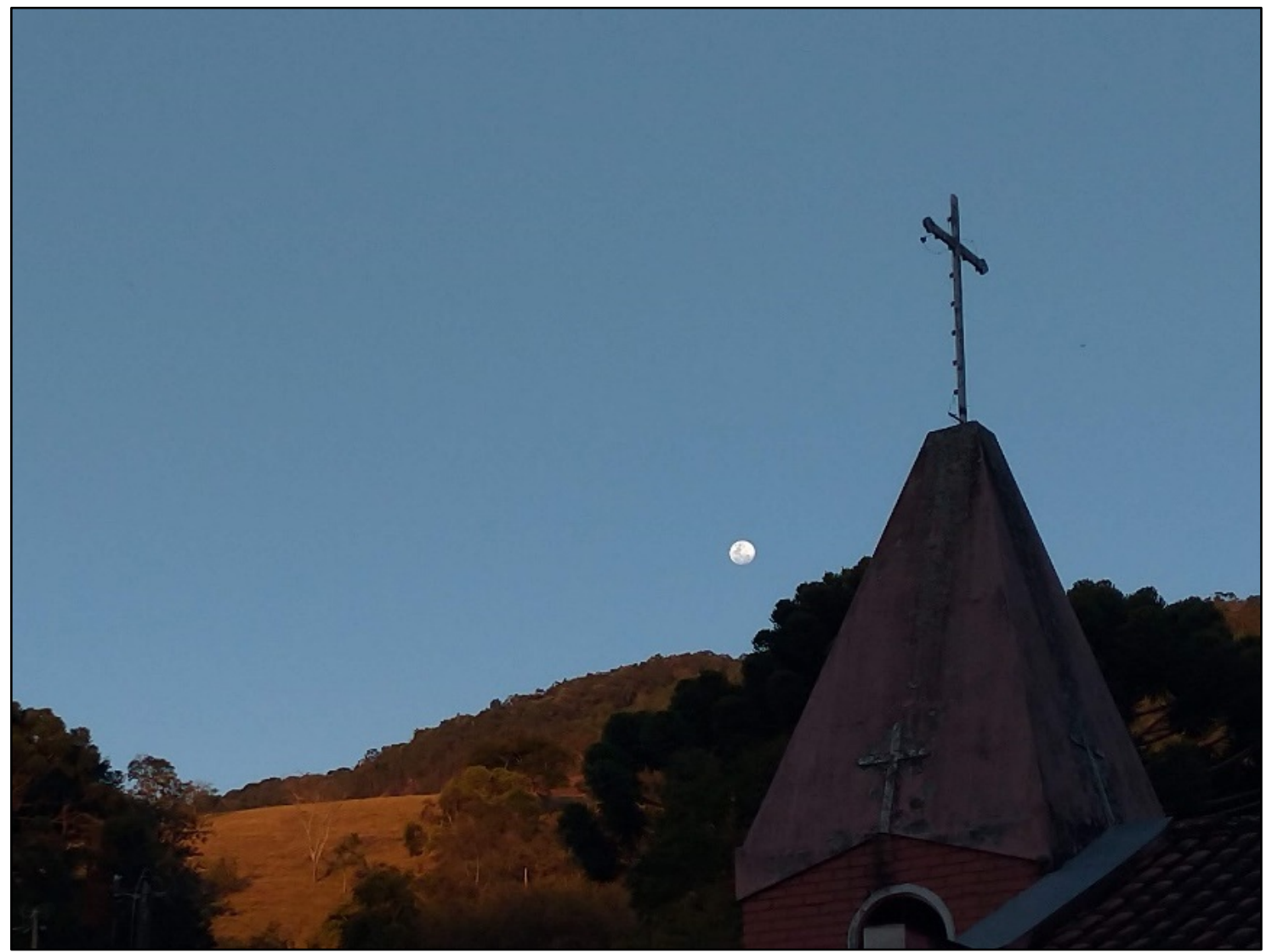

Fotografia 23: O anoitecer na Peroba. 


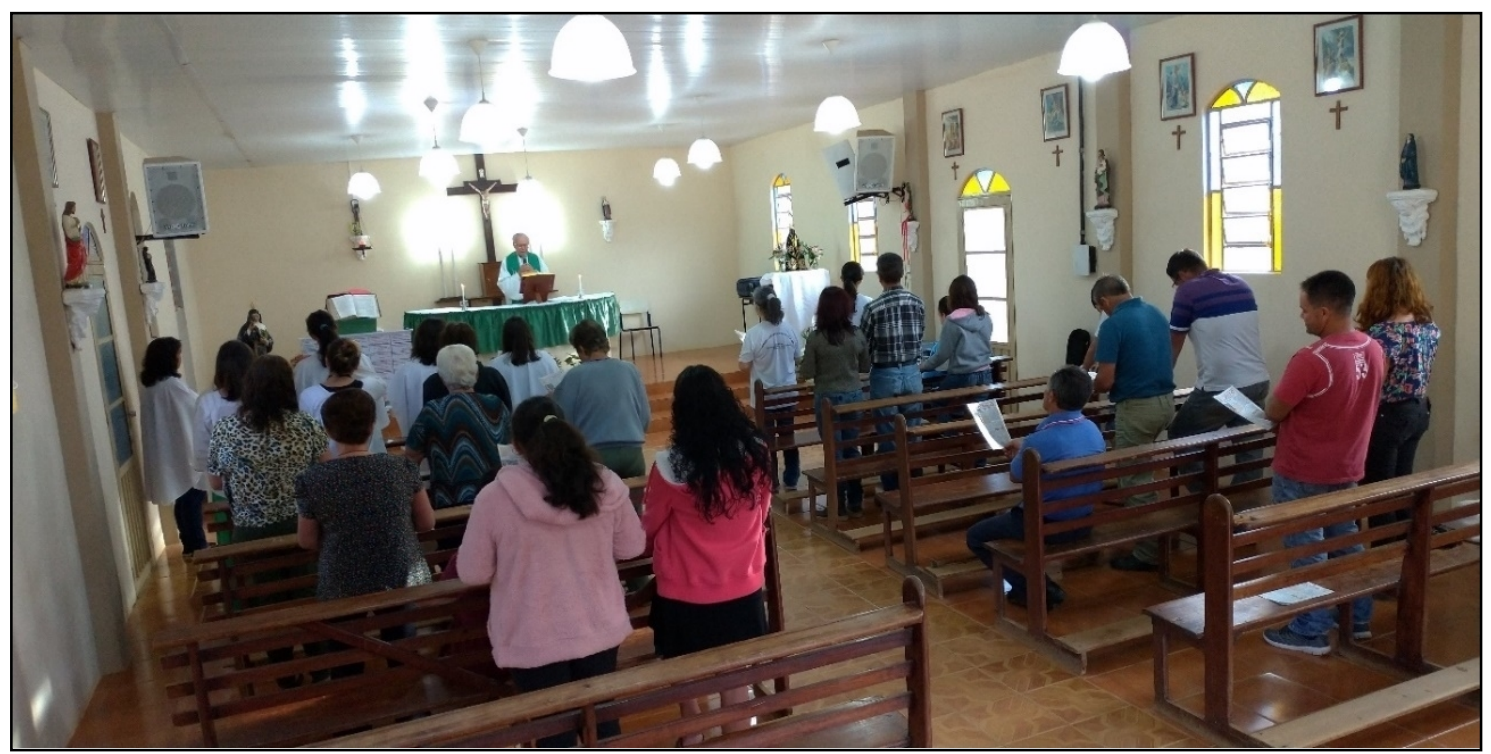

Fotografia 24: Missa mensal na Igreja de Santa Rita de Cássia.

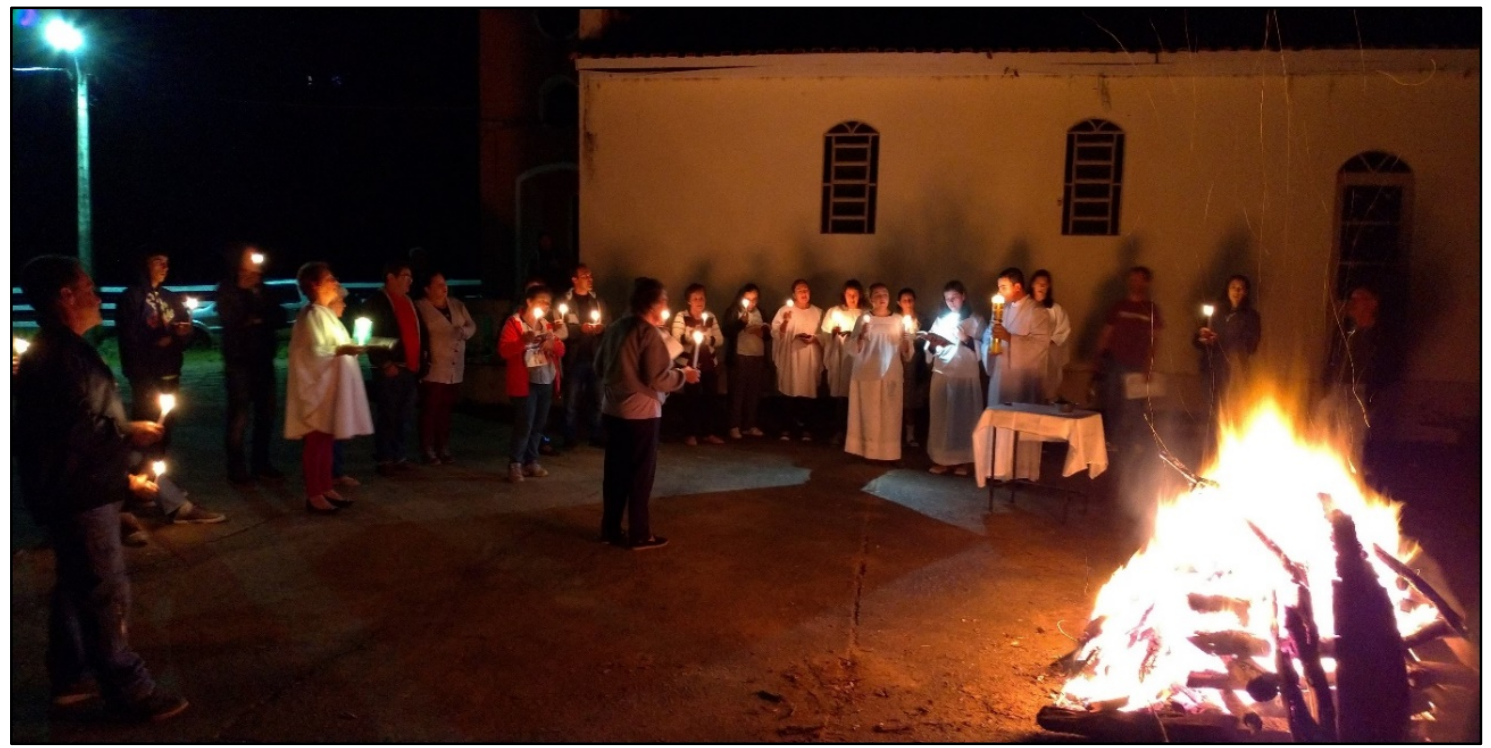

Fotografia 25: Celebração da Vigília Pascal em 20 de abril de 2020. Momento da Bênção do Fogo Novo.

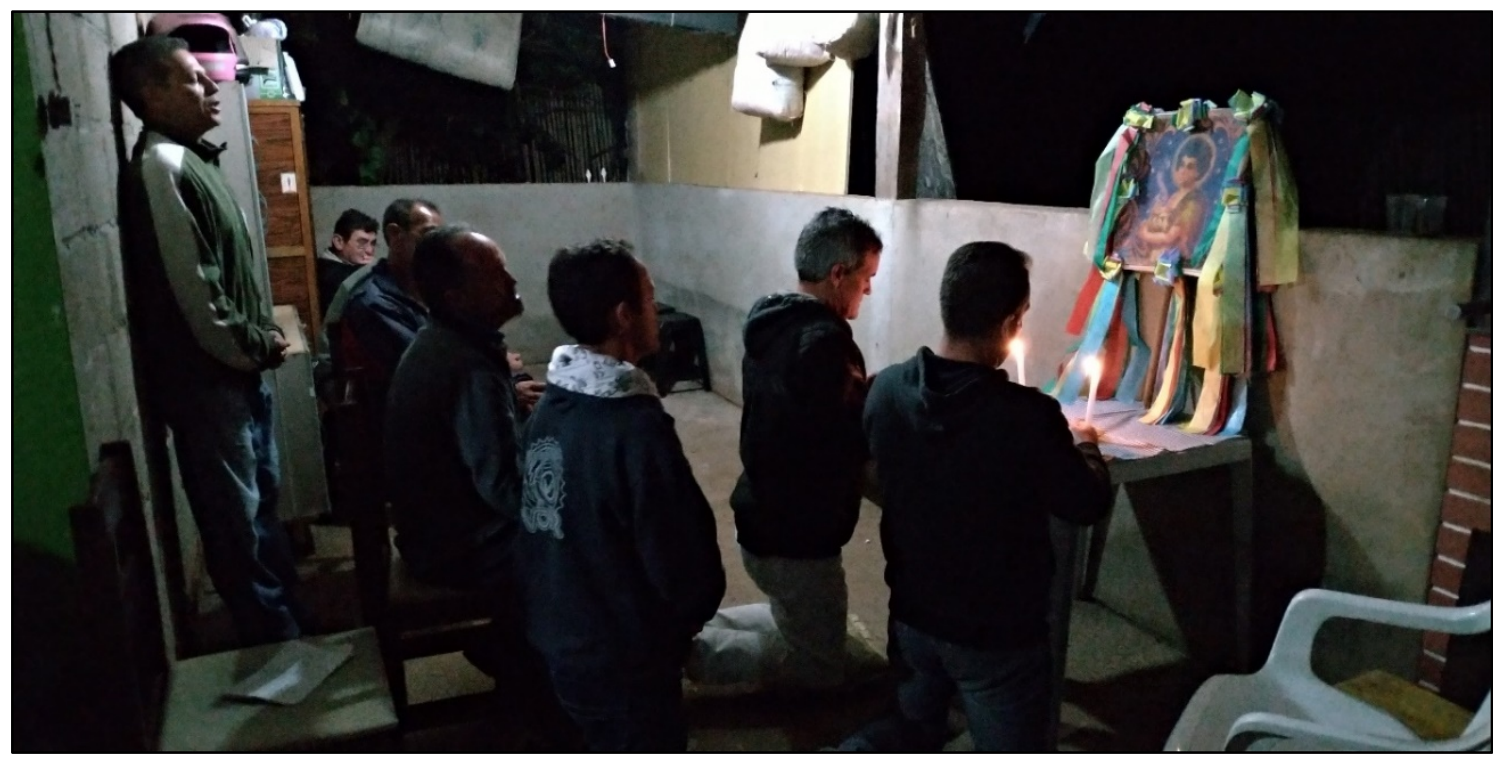

Fotografia 26: Terço cantando pelos homens da Peroba. 